\title{
POTRET IMPLEMENTASI PENDIDIKAN KARAKTER DI SMP KECAMATAN PATUMBAK SUMATERA UTARA
}

\author{
Derlina $^{1}$, Putri Srijayanti ${ }^{2}$ \\ ${ }^{1,2}$ Universitas Negeri Medan, Jl. Willem Iskandar Pasar V-Kotak Pos No. 1589 Medan 20221; \\ e-mail: derlina.nst@gmail.com
}

Diterima: 21 September 2016. Disetujui: 10 Oktober 2016. Dipublikasikan: Oktober 2016

\begin{abstract}
Abstrak: Penelitian ini bertujuan untuk mengetahui implementasi pendidikan karakter pada mata pelajaran IPA di SMP se-kecamatan Patumbak T.P. 2015/2016. Jenis penelitian ini adalah deskriptif studi kasus. Populasi dalam penelitian adalah seluruh siswa kelas VIII masing-masing SMP T.P. 2015/2016. Pengambilan sampel dilakukan secara acak sebanyak 25\% dari jumlah keseluruhan SMP Se-Kecamatan Patumbak yaitu SMPN 1 Patumbak, SMPS Madani Marindal, SMPS Ponpes Al-Husna dan SMPS IT Rahmat. Instrumen yang digunakan yaitu lembar observasi, catatan harian wawancara dan angket (kuesioner) yang dibantu oleh satu observer. Dari hasil penelitian diperoleh jumlah nilai pendidikan karakter yang diimplementasikan setiap sekolah SMP, yaitu pada SMP Negeri 1 Patumbak menerapkan 9 nilai karakter dengan persentase 50\%, SMP Swasta Madani Marindal 1 menerapkan 11 nilai karakter dengan persentase 55\%, SMP Swasta Ponpes Al-Husna menerapkan 13 nilai karakter dengan persentase 72\%, dan SMP Swasta IT Rahmat menerapkan 9 nilai karakter dengan persentase 50\%.
\end{abstract}

Kata kunci: deskriptif studi kasus, implementasi pendidikan karakter, pelajaran IPA

\section{THE DESCRIPTION OF THE IMPLEMENTATION OF CHARACTER EDUCATION IN JUNIOR HIGH SCHOOL PATUMBAK DISTRICT, NORTH SUMATRA}

\begin{abstract}
This study aims to determine the implementation of character education in science subjects in junior high school districts Patumbak TP 2015/2016. This research is a descriptive case study. The population in the study were all students of class VIII SMP respectively TP 2015/2016. The sampling is done randomly as much as $25 \%$ of the total number of sub-district Junior High School in Patumbak ie, SMPN 1 Patumbak, SMPS Madani Marindal, SMPS Pesantren Al-Husna, and SMPS IT Rahmat. The instruments used are observation sheets, diaries interviews and questionnaires (questionnaire) assisted by one observer. The results are obtained, sum of the values of character education is implemented in every secondary school ie,; at SMP Negeri 1 Patumbak apply 9 character values with a percentage of 50\%, SMPS Madani Marindal 1 apply 11 character values with a percentage of 55\%, SMPS Pesantren Al-Husna apply 13 character values with the percentage of 72\%, and SMPS IT Rahmat apply 9 character values with a percentage of $50 \%$.
\end{abstract}

(C) 2016 Pendidikan Fisika, FTK IAIN Raden Intan Lampung

Keywords: descriptive case studies, implementation of character education, science subjects

\section{PENDAHULUAN}

Pendidikan nilai/moral sangat diperlukan atas dasar argumen: adanya kebutuhan nyata dan mendesak, serta peranan sekolah sebagai pendidik moral yang vital pada saat melemahnya pendidikan nilai dalam masyarakat.
Tantangan globalisasi yang semakin kuat dan beragam, serta proses pendidikan yang lebih mementingkan penguasaan dimensi pengetahuan (knowledge) dan hampir mengabaikan pendidikan nilai/moral saat ini, merupakan alasan yang kuat bagi Indonesia untuk 
membangkitkan komitmen dan melakukan gerakan nasional pendidikan karakter. Lebih jauh dari itu adalah Indonesia dengan masyarakatnya yang ber-Bhinneka tunggal ika dan dengan falsafah negaranya Pancasila yang sarat dengan nilai dan moral, merupakan alasan filosofik ideologis sekaligus sosialkultural tentang pentingnya pendidikan karakter untuk dibangun dan dilaksanakan secara nasional dan berkelanjutan (Sjarkawi, 2006:11).

Pembangunan karakter yang merupakan upaya perwujudan amanat Pancasila dan Pembukaan UUD 1945 dilatarbelakangi oleh realita permasalahan kebangsaan yang berkembang saat ini, seperti: disorientasi dan belum dihayatinya nilai-nilai Pancasila; keterbatasan perangkat kebijakan terpadu dalam mewujudkan nilai-nilai Pancasila; bergesernya nilai etika dalam kehidupan berbangsa dan bernegara; memudarnya kesadaran terhadap nilai-nilai budaya bangsa; ancaman disintegrasi bangsa; dan melemahnya kemandirian bangsa (Depdiknas, 2010: 5).

Dalam konteks kehidupan bermasyarakat, berbangsa dan bernegara Indonesia, bahwa pendidikan nasional berfungsi mengembangkan kemampuan serta membentuk watak serta peradaban bangsa yang bermartabat dalam rangka mencerdaskan kehidupan bangsa, bertujuan untuk mengembangkan potensi peserta didik agar menjadi manusia yang beriman dan bertaqwa kepada Tuhan Yang Maha Esa, berakhlak mulia, sehat, berilmu, cakap, kreatif, mandiri, dan menjadi warga negara yang demokratis dan bertanggung jawab, harus dimiliki peserta didik mampu menghadapi tantangan hidup pada saat ini dan dimasa mendatang. Karena itu, pengembangan nilai yang bermuara pada pembentukan karakter bangsa yang diperoleh melalui berbagai jalur, jenjang, dan jenis pendidikan, akan mendorong mereka menjadi anggota masyarakat, anak bangsa, dan warga Negara yang memiliki kepribadian unggul seperti diharapkan dalam tujuan pendidikan nasional. Sampai saat ini, secara kurikuler telah dilakukan berbagai upaya untuk menjadikan pendidikan lebih mempunyai makna bagi individu yang tidak sekedar memberi pengetahuan pada tataran kognitif, tetapi juga menyentuh tataran afektif dan konatif melalui mata pelajaran Pendidikan Agama, Pendidikan Kewarganegaraan, Pendidikan IPS, Pendidikan Bahasa Indonesia dan Pendidikan Jasmani. Namun demikian harus diakui karena kondisi jaman yang berubah dengan cepat, maka upaya-upaya tersebut ternyata belum mampu untuk mewadahi pengembangan karakter secara dinamis dan adaptif terhadap perubahan tersebut. Oleh karena itu, pendidikan karakter perlu dirancang ulang dan dikemas kembali dalam wadah yang lebih komprehensif dan lebih bermakna. Pendidikan karakter perlu direformulasikan dan direoperasionalkan melalui transformasi budaya dan dimensi kehidupan.

Kebutuhan tersebut bukan hanya dianggap penting tetapi sangat mendesak mengingat berkembangnya godaangodaan (temptations) dewasa ini marak dengan tayangan dalam media cetak maupun non-cetak (televisi, internet, dan lain-lain) yang memuat fenomena dan kasus perseteruan dalam berbagai kalangan yang memberi kesan seakanakan bangsa kita sedang mengalami krisis etika dan krisis kepercayaan diri yang berkepanjangan. Pendidikan karakter bangsa diharapkan mampu menjadi alternatif solusi berbagai persoalan tersebut. Kondisi dan situasi saat ini tampaknya menuntut pendidikan karakter yang perlu ditransformasikan sejak dini, yaitu sejak pendidikan anak usia dini dan pada tahap pendidikan dasar secara holistik dan berkesinambungan (Sani, 2011: 11-13)

Beberapa penelitian telah dilakukan diberbagai wilayah dan tingkat 
pendidikan antara lain Zuhriy (2011: 307) menemukan bahwa budaya disiplin, budaya mandiri, budaya bersih dan rapi dan budaya peduli lingkungan terbentuk pada diri siswa pondok pesantren akibat dari kebiasaan-kebiasaan yang dikonstruk oleh pesantren untuk setiap santrinya yang diatur selama 24 jam full. Mukromin (2010: 138) juga menemukan bahwa pembentukan karakter di pondok pesantren diselenggarakan secara terpadu dalam pembelajaran dan melalui pembiasaan yang diperhatikan selama 24 jam siang dan malam. Dengan demikian, pendidikan karakter dipahami sebagai suatu sistem penanaman nilai-nilai karakter yang baik kepada semua yang terlibat dan sebagai warga sekolah sehingga mempunyai pengetahuan, kesadaran, dan tindakan dalam melaksanakan nilai-nilai tersebut.Semua warga sekolah yang terlibat dalam pengembangan karakter yang baik ini sesungguhnya dalam rangka membangun karakter anak didik.Hal ini penting agar anak didik menemukan contoh dan lingkungan yang kondusif dengan karakter baik yang sedang dibangun dalam kepribadiannya (Siswanto, 2013:97-98).

Perbedaan penelitian ini dengan penelitian sebelumnya adalah penelitian yang biasanya hanya dilakukan di Pondok Pesantren yang jelas aturan nilai-nilai religiusnya mengikat siswa selama 24 jam, maka peneliti berusaha mengganti objek penelitian untuk dilakukan di sekolah SMP negeri dan swasta yang siswanya tidak terkontrol secara penuh oleh pihak sekolah serta membandingkannya dengan satu pondok pesantren.

Sebagai bahan perbandingan untuk mengetahui sejauh mana sekolah tersebut menerapkan pendidikan karakter bagi peserta didiknya sebagai konteks dalam menerapkan tujuan pendidikan nasional. Perbandingan yang diperoleh dari penelitian ini adalah peneliti dapat membandingkan potret implementasi pendidikan karakter untuk tiap sekolah dalam segi yag berbeda, antara sekolah negeri, sekolah swasta maupun pondok pesantren. Dan penelitian ini juga akan semakin menarik karena setiap pengimplementasian pendidikan karakter tersebut akan diteliti kaitannya pada Mata Pelajaran IPA di sekolah tersebut.

\section{METODE PENELITIAN}

Penelitian ini difokuskan pada implementasi pendidikan karakter dalam mata pelajaran IPA di Kecamatan Patumbak Deli Serdang Sumatera Utara. Pengambilan sampel dalam penelitian ini yaitu sebanyak $25 \%$ dari jumlah keseluruhan sekolah di Kecamatan Patumbak. Sehingga peneliti mengambil sampel sebanyak 4 sekolah, yang terdiri dari 1 sekolah negeri dan 3 sekolah swasta (termasuk 1 sekolah swasta berbasis pondok pesantren). Berdasarkan tempat penelitian, yang menjadi populasi penelitian adalah seluruh siswa kelas VIII masing - masing SMP T.P. 2015/2016. Sampel dalam penelitian ini terdiri dari satu kelas untuk masing - masing SMP, yaitu SMP Negeri 1 Patumbak, SMP Swasta IT Rahmat, SMP Swasta Pondok Pesantren Al-Husna dan SMP Swasta Madani Marindal.

Jenis penelitian dalam penelitian ini adalah penelitian deskriptif studi kasus. Penelitian ini diarahkan untuk menetapkan sifat suatu situasi pada waktu penyelidikan itu dilakukan.

Dalam penelitian deskriptif studi kasus, pengumpulan data dilakukan pada natural setting (kondisi yang alamiah), sumber data primer, dan teknik pengumpulan data yang dilakukan lebih banyak pada observasi, wawancara, dan kajian dokumen (study document).

\section{HASIL DAN PEMBAHASAN}

Penelitian yang dilakukan di keempat sekolah tersebut memiliki hasil sebagai berikut : (1) Pada SMP Negeri 1 
Patumbak menerapkan 9 nilai pendidikan karakter yang disyaratkan, seperti religius, demokrasi, jujur, rasa ingin tahu, toleransi, semangat kebangsaan, disiplin, peduli lingkungan, kerja keras; (2) Pada SMP Swasta Madani Marindal 1 menerapkan 10 nilai pendidikan karakter yaitu religius, demokrasi, jujur, rasa ingin tahu, toleransi, semangat kebangsaan, disiplin, peduli lingkungan, kerja keras, dan tanggung jawab; (3) Pada SMP Swasta Pondok Pesantren Al-Husna menerapkan 13 nilai pendidikan karakter yaitu religius, mandiri, jujur, rasa ingin tahu, toleransi, semangat kebangsaan, disiplin, peduli lingkungan, peduli sosial, kerja keras, tanggung jawab, kreatif, dan inovatif; dan (4) Pada SMP Swasta IT Rahmat menerapkan 9 nilai pendidikan karakter yaitu religius, jujur, rasa ingin tahu, toleransi, semangat kebangsaan, disiplin, peduli lingkungan, kerja keras, tanggung jawab

Secara lebih rinci persentase jumlah nilai karakter yang muncul pada keempat sekolah dapat dilihat pada tabel 1 berikut ini :

$\underline{\text { Tabel 1. Persentase Nilai Pendidikan Karakter }}$

\begin{tabular}{|c|c|c|c|}
\hline No & Nama Sekolah & $\begin{array}{c}\text { Jumlah } \\
\text { Nilai } \\
\text { Karakter } \\
\text { yang } \\
\text { Diterapkan } \\
\end{array}$ & $\%$ \\
\hline 1 & $\begin{array}{l}\text { SMPN 1 } \\
\text { Patumbak }\end{array}$ & 9 & $50 \%$ \\
\hline 2 & $\begin{array}{l}\text { SMPS Madani } \\
\text { Marindal }\end{array}$ & 10 & $55 \%$ \\
\hline 3 & $\begin{array}{l}\text { SMPS Ponpes Al- } \\
\text { Husna }\end{array}$ & 13 & $72 \%$ \\
\hline 4 & SMPS IT Rahmat & 9 & $50 \%$ \\
\hline
\end{tabular}

Berdasarkan rekapitulasi data hasil penelitian untuk keempat sekolah tersebut, maka dapat digambarkan melalui diagram pada gambar 1 berikut:

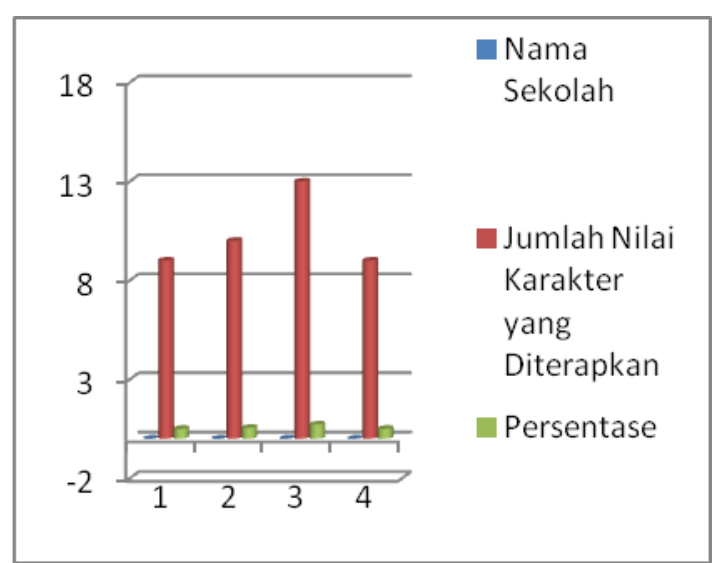

Gambar 1. Rekapitulasi data hasil penelitian

Fokus penelitian ini terdiri dari nilai-nilai pendidikan karakter yaitu religius, mandiri, demokratis, semangat kebangsaan, cinta tanah air, peduli sosial dan tanggungjawab. Dalam hal ini sebagai subjek model pendidikan karakter tersebut adalah guru sebagai pembimbing dan motivator untuk mencapai nilai-nilai pendidikan karakter tersebut.

1. Religiuitas adalah sikap dan perilaku yang patuh dalam melaksanakan ajaran agama yang dianutnya, dan indikatornya adalah guru memberikan kesempatan kepada semua peserta didik untuk melaksanakan ibadah, toleran terhadap pelaksanaan ibadah agama lain, serta hidup rukun dengan pemeluk agama lain. Dan nilai-nilai yang diterapkan dalam proses pembelajaran itu antara lain guru membimbing siswa untuk berdoa sebelum pelajaran dimulai dan memberikan kesempatan kepada siswa untuk menjalankan ibadahnya masing-masing.

2. Mandiri adalah sikap dan perilaku yang tidak mudah tergantung pada orang lain dalam menyelesaikan tugas-tugas. Indikatornya adalah menciptakan situasi sekolah yang membangun kemandirian peserta didik, dan nilai-nilai yang diterapkan dalam proses pembelajaran itu antara lain guru membimbing siswa untuk mengerjakan tugas masing-masing dan guru memotivasi siswa agar 
mengerjakan pekerjaannya agar lebih baik lagi.

3. Demokratis adalah cara berpikir, bersikap, dan bertindak yang menilai sama hak dan kewajiban dirinya dan orang lain, dan indikatornya adalah menciptakan situasi sekolah yang membangun kemandirian peserta didik, dan nilai-nilai yang diterapkan adalah guru membimbing siswa untuk mengerjakan tugas masing-masing, guru memotivasi siswa agar mengerjakan pekerjaannya agar lebih baik lagi.

4. Semangat kebangsaan adalah cara berpikir, bertindak, dan berwawasan yang menempatkan kepentingan bangsa dan Negara di atas kepentingan diri dan kelompoknya, indikatornya adalah bahwa menciptakan suasana sekolah yang menerima perbedaan, dan nilai-nilai yang diterapkan adalah Guru menghargai pendapat siswa, guru menghargai hasil pekerjaan siswa.

5. Cinta tanah air adalah cara berpikir, bersikap, dan berbuat yang menunjukkan kesetiaan, kepedulian, dan penghargaan yang tinggi terhadap bahasa, lingkungan fisik, sosial, budaya, ekonomi, dan politik bangsa, dan indikatornya adalah menjaga lingkungan, dan nilai-nilai pendidikan karakternya adalah bahwa guru mengarahkan supaya siswa menghargai perbedaan suku, guru membimbing siswa untuk membuang sampah pada tempatnya.

6. Peduli sosial adalah sikap dan tindakan yang selalu ingin memberi bantuan kepada orang lain dan masyarakat yang membutuhkan, indikatornya melalui aksi sosial, dan nilai-nilai pendidikan karakternya adalah bahwa guru mengarahkan siswa untuk menjenguk siswa dan guru yang sakit, memberikan sumbangan kepada siswa dan guru yang terkena musibah.
7. Tanggungjawab adalah sikap dan perilaku seseorang untuk melaksanakan tugas dan kewajibannya, yang seharusnya dia lakukan, terhadap diri sendiri, masyarakat, lingkungan (alam, sosial, dan budaya), Negara dan Tuhan Yang Maha Esa. indikatornya dalah peran serta aktif guru dalam kegiatan sekolah, dan nilai-nilai pendidikan karakternya adalah mengajari siswa dengan kesabaran dan menjaga nama baik sekolah. Nilai-nilai pendidikan karakter itu diaplikasikan pada setiap mata pelajaran yang diajarkan oleh setiap guru.

Pendidikan karakter sangat strategis bagi keberlangsungan dan keunggulan suatu bangsa, prestasi serta kemampuan lainnya terbentuk ketika sikap yang baik juga ikut terbentuk. Hal ini sejalan dengan pendapat Skaggs \& Bondenhorn (2006: 113) bahwa pendidikan karakter akan membentuk kemampuan siswa terutama prestasi siswa, karena siswa yang mampu mempertahankan diri dalam membentuk karakter positif terus-menerus, maka dengan sendirinya karakter-karakter tersebut akan membentuk kemandirian menuju siswa yang berprestasi. Pendapat yang sama juga disampaikan oleh Jaya, Jaya,dkk (2014: 1) bahwa peningkatan karakter dan hasil belajar siswa dapat diperoleh ketika perangkat pembelajaran memenuhi kriteria valid, praktis dan efektif sehingga dapat digunakan dalam lingkup yang lebih luas, Hal yang sama juga dijelaskan oleh Benninga, et.al (2003: 30) bahwa pendidikan karakter yang baik dapat berjalan ketika dikembangkan dengan baik, ketika sekolah berperan dalam menciptakan kondisi dimana peraturan yang menuju pembentukan karakter dijalankan dengan baik, maka pengembangan dan peningkatan prestasi siswa akan semakin meningkat dan terbentuklah bibit-bibit unggul baru yang berpotensi. Karakter sendiri ada yang alamiah dan ada pula 
yang tercipta melalui latihan dan kebiasaan. Fungsi pendidikan adalah transformasi kebudayaan dan nilai kepada peserta didik, agar mampu memahami, menginternalisasikan dan menyampaikan kepada generasi berikutnya. Hal serupa juga dijelaskan oleh Suharjana (2012: 189) yang berpendapat bahwa Pendidikan karakter dapat dikembangkan melalui tahap pengetahuan (knowing), pelaksanaan (acting), dan kebiasaan (habit). Setiap hari manusia akan menjalani aktivitas rutin seperti makan, istirahat, mandi, dan beraktivitas lainnya. Jika kegiatan rutin ini dimanagemen dengan baik sesuai dengan kaidah-kaidah yang benar, akan menjadi kebiasaan yang baik yang seterusnya akan menghasilkan nilai-nilai karakter yang positif. Hal tersebut sejalan dengan pendapat Mukromin (2010: 143) yang menjelaskan bahwa ada dua faktor pendidikan ialah faktor eksternal, yaitu nilai dan kebudayaaan, serta faktor internal berupa aktualisasi potensi yang dimiliki. Kedua faktor ini sama kuat pengaruhnya, awalnya keadaan ini terjadi karena dipertimbangkan dan dipikirkan, namun kemudian praktik secara terus-menerus dan menjadi suatu kebiasaan.

\section{Implementasi Pendidikan Karakter} A. SMPN 1 Patumbak

Implementasi pendidikan karakter di SMP Negeri 1 Patumbak, dijelaskan sebagai berikut:

1. Religius, dengan contoh kegiatan berdoa sebelum dan sesudah pelajaran

2. Demokrasi, dengan contoh kegiatan saat berdiskusi, siswa diminta memberikan pendapatnya masingmasing setiap kelompok

3. Jujur, dengan contoh kegiatan Saat tugas dikumpulkan, siswa yang tidak mengerjakan tugas mengakui tidak mengerjakan tugasnya dan akan diberikan hukuman oleh guru yang bersangkutan
4. Rasa ingin tahu, dengan contoh kegiatan saat diskusi, siswa bertanya hal-hal yang tidak diketahuinya

5. Toleransi, dengan contoh kegiatan saat hari jumat, siswa saling bertoleransi, menghormati agama yang lainnya, dimana yang beragama islam melakukan pengajian, dan yang non muslim berkumpul untuk berdoa bersama di aula

6. Semangat kebangsaan, dengan contoh kegiatan saat upacara berlangsung, siswa bersemangat menyanyikan lagu Indonesia raya dan lagu nasional lainnya

7. Disiplin, dengan contoh kegiatan siswa yang datang terlambat dihukum untuk membersihkan kamar mandi, mengutip sampah dan hormat bendera

8. Peduli lingkungan, dengan contoh kegiatan Jumat bersih dilakukan agar siswa peduli lingkungan sekitarnya

9. Kerja keras, dengan contoh kegiatan sebelum ujian akhir dilaksanakan, siswa diberikan les tambahan untuk meningkatkan kerja keras siswa dalam menghadapi pembelajaran

\section{B. SMPS Madani Marindal}

Implementasi pendidikan karakter di SMP Swasta Madani Marindal, dapat dijelaskan sebagai berikut:

1. Religius, dengan contoh kegiatan berdoa sebelum dan sesudah pelajaran

2. Demokrasi, dengan contoh kegiatan saat berdiskusi, siswa diminta memberikan pendapatnya masingmasing setiap kelompok

3. Jujur, dengan contoh kegiatan saat tugas dikumpulkan, siswa yang tidak mengerjai tugas mengakui tidak mengerjakan tugasnya dan akan diberikan hukuman oleh guru yang bersangkutan

4. Rasa ingin tahu, dengan contoh kegiatan saat diskusi, siswa bertanya hal-hal yang tidak diketahuinya

5. Toleransi, dengan contoh kegiatan saat hari jumat, siswa saling 
bertoleransi, dimana saat pembacaan beberapa ayat Al-Qur'an setiap siswa melafalkan dengan baik

6. Semangat kebangsaan, dengan contoh kegiatan Saat upacara berlangsung, siswa bersemangat menyanyikan lagu Indonesia raya dan lagu nasional lainnya

7. Disiplin, dengan contoh kegiatan Siswa yang datang terlambat dihukum untuk membersihkan kamar mandi, mengutip sampah dan hormat bendera

8. Peduli lingkungan, dengan contoh kegiatan Jumat bersih dilakukan agar siswa peduli lingkungan sekitarnya

9. Kerja keras, dengan contoh kegiatan Sebelum ujian akhir dilaksanakan, siswa diberikan les tambahan untuk meningkatkan kerja keras siswa dalam menghadapi pembelajaran.

10. Tanggung jawab, dengan contoh kegiatan Siswa yang tidak mengerjai tugas bertanggung jawab dengan diberi sanksi untuk mengerjakan kembali tugasnya sampai selesai di hari itu juga

\section{SMPS Ponpes Al-Husna}

Untuk implementasi pendidikan karakter di SMP Swasta Pondok Pesantren AL-Husna, dapat dijelaskan sebagai berikut:

1. Religius, dengan contoh kegiatan Berdoa sebelum dan sesudah pelajaran

2. Mandiri, dengan contoh kegiatan Siswa mengerjakan semua kerjaan pribadinya sendiri, seperti mencuci baju

3. Jujur, dengan contoh kegiatan Saat tugas dikumpulkan, siswa yang tidak mengerjai tugas mengakui tidak mengerjai tugasnya dan akan diberikan hukuman oleh guru yang bersangkutan

4. Rasa ingin tahu, dengan contoh kegiatan saat diskusi, siswa bertanya hal-hal yang tidak diketahuinya

5. Toleransi, dengan contoh pengajian, dan yang non muslim kegiatan saat hari jumat, siswa saling bertoleransi, menghormati agama yang lainnya, dimana yang beragama islam melakukan berkumpul untuk berdoa bersama di aula

6. Semangat kebangsaan, dengan contoh kegiatan saat upacara berlangsung, siswa bersemangat menyanyikan lagu Indonesia raya dan lagu nasional lainnya

7. Disiplin, dengan contoh kegiatan siswa yang datang terlambat dihukum untuk membersihkan kamar mandi, mengutip sampah dan hormat bendera

8. Peduli lingkungan, dengan contoh kegiatan Jumat bersih dilakukan agar siswa peduli lingkungan sekitarnya

9. Kerja keras, dengan contoh kegiatan sebelum ujian akhir dilaksanakan, siswa diberikan les tambahan untuk meningkatkan kerja keras siswa dalam menghadapi pembelajaran

10. Peduli sosial, dengan contoh kegiatan siswa di bulan puasa saling berbagi makanan kepada masyarakat sekitar pondok pesantren

11. Tanggung jawab, dengan contoh kegiatan siswa yang merokok bertanggung jawab atas kesalahannya dan menerima hukuman untuk dibotak, biasanya terjadi pada siswa laki-laki

12. Kreatif, dengan contoh kegiatan saat hari Pendidikan Nasional, sekolah mengadakan lomba memasak, menghias kamar dan lain-lain

13. Inovatif, dengan contoh kegiatan siswa membuat kerajinan dari bahanbahan sederhana, misalnya memuat bunga dari kertas Koran

\section{SMPS IT Rahmat}

Implementasi pendidikan karakter di SMP Swasta IT Rahmat, dapat dijelaskan sebagai berikut:

1. Religius, dengan contoh kegiatan berdoa sebelum dan sesudah pelajaran

2. Tanggung jawab, dengan contoh kegiatan siswa yang tidak 
mengerjakan tugas diminta pertanggung jawabannya untuk mengerjakan tugasnya kembali sampai selesai dengan waktu yang sudah ditentukan

3. Jujur, dengan contoh kegiatan saat tugas dikumpulkan, siswa yang tidak mengerjai tugas mengakui tidak mengerjakan tugasnya dan akan diberikan hukuman oleh guru yang bersangkutan

4. Rasa ingin tahu, dengan contoh kegiatan saat diskusi, siswa bertanya hal-hal yang tidak diketahuinya

5. Toleransi, dengan contoh kegiatan saat hari jumat, siswa saling bertoleransi, menghormati agama yang lainnya, dimana yang beragama islam melakukan pengajian, dan yang non muslim berkumpul untuk berdoa bersama di aula

6. Semangat kebangsaan, dengan contoh kegiatan saat upacara berlangsung, siswa bersemangat menyanyikan lagu Indonesia raya dan lagu nasional lainnya

7. Disiplin, dengan contoh kegiatan siswa yang datang terlambat dihukum untuk membersihkan kamar mandi, mengutip sampah dan hormat bendera

8. Peduli lingkungan, dengan contoh kegiatan Jumat bersih dilakukan agar siswa peduli lingkungan sekitarnya

9. Kerja keras, dengan contoh kegiatan sebelum ujian akhir dilaksanakan, siswa diberikan les tambahan untuk meningkatkan kerja keras siswa dalam menghadapi pembelajaran

\section{Nilai Pendidikan Karakter dalam Hubungannya dengan Diri Sendiri}

Nilai-nilai pendidikan karakter dalam hubungannya dengan diri sendiri yang ditanamkan kepada para siswa SMP menjadi faktor penting dalam pelaksanaan pendidikan karakter. Temuan ini memberikan kontribusi penting dimana pengembangan karakter siswa yang semakin mendalam tentang nilai-nilai diri sendiri menunjukkan semakin dapat membentuk karakter pribadi siswa yang berkarakter.

Lingkungan kelas yang kondusif untuk pengembangan karakter disiplin siswa ini penting diperhatikan terutama untuk tingkat sekolah menengah karena anak-anak usia sekolah tersebut akan lebih mudah dikembangkan karakternya melalui berbagai kegiatan/aktivitas kelas. Hal tersebut sejalan dengan penelitian Salirawati (2012: 213) yang berpendapat bahwa penanaman nilai karakter yang terintegrasi dalam semua mata pelajaran dapat diharapkan nilai-nilai tersebut terinternalisasi dalam diri peserta didik. Materi yang dibelajarkan tidak hanya sebagai pengetahuan sekolah, tetapi juga menjadi pengetahuan dalam diri yang akhirnya ditunjukkan dalam bentuk perilaku

Hasil temuan ini sesuai dengan visi misi keempat sekolah yang menjunjung tinggi nilai sikap dan perilaku siswa yang positif. Dari temuan ini diharapkan sekolah yang melaksanakan pendidikan khususnya dalam pengembangan pendidikan karakter harus tetap menjaga dan mengedepankan nilai-nilai kepribadian dalam proses pembelajaran di sekolah. Hasil penelitian yang sama oleh Ikhwanuddin (2012: 153) menunjukkan bahwa implementasi pendidikan karakter kerja keras dan kerja sama mampu meningkatkan skill dan prestasi belajar mahasiswa. Prestasi belajar dianggap sebagai efek samping pendidikan karakter pada proses pembelajaran.

\section{Nilai Pendidikan Karakter dalam Hubungannya dengan Alam}

Nilai-nilai karakter dalam hubungannya dengan alam yang ditanamkan kepada para siswa SMP menjadi faktor penting dalam pelaksanaan pendidikan karakter. Temuan ini memberikan kontribusi penting dimana pengembangan karakter siswa yang semakin mendalam tentang nilai-nilai 
terhadap alam menunjukkan semakin dapat membentuk karakter pribadi sswa yang berkarakter. Hasil temuan ini sesuai dengan visi misi keempat sekolah, yaitu melaksanakan kegiatan ekstrakurikuler secara terprogram dan berkesinambungan. Dari temuan ini diharapkan sekolah yang melaksanakan pendidikan khususnya dalam pengembangan pendidikan karakter harus tetap menjaga dan mengedepankan nilai-nilai terhadap alam dalam proses pembelajaran di sekolah.

Secara spesifik, temuan ini menyimpulkan bahwa siswa SMP dapat dikatakan memiliki karakter dalam hubungannya dengan alam apabila didasarkan pada: pertama, bahwa siswa harus memiliki nilai-nilai sikap kepribadian yang gemar menjaga kebersihan. Oleh karena itu, nilai-nilai pribadi siswa tentang menjaga kebersihan harus berlandaskan pada keinginan untuk menjaga lingkungan yang sehat. Kedua, bahwa siswa harus memiliki nilai-nilai sikap kepribadian yang gemar memelihara tanaman. Ketiga, bahwa siswa harus memiliki nilai-nilai sikap kepribadian yang senang memelihara hewan. Keempat, bahwa siswa harus memiliki nilai-nilai sikap kepribadian yang peka terhadap lingkungan hidup. Oleh karena itu, nilai-nilai pribadi siswa tentang sikap kepribadian yang peka terhadap lingkungan hidup menjadi faktor penting dalam pendidikan karakter karena dalam lingkungan hidup siswa harus menjaga sumber daya alam. Kelima, bahwa siswa harus memiliki nilai-nilai sikap kepribadian yang senang berada di cagar alam, hal ini menjadi faktor penting dalam pendidikan karakter karena dengan kegemaran ini siswa didorong untuk berinteraksi dengan alam secara luas. Keenam, bahwa siswa harus memiliki nilai-nilai sikap kepribadian yang peduli sosial dan lingkungan.

\section{Pembahasan Rencana Pelaksanaan Pembelajaran (RPP)}

Kebanyakan dari perilaku disiplin dalam aktivitas kelas sehari-hari tidak tertulis secara jelas dalam rencana pelaksanaan pembelajaran (RPP) yang dibuat oleh guru. Sebagian besar berbentuk kurikulum tersembunyi yang diwujudkan dalam perilaku guru seharihari. Kedisiplinan guru dalam memasuki ruang kelas, memakai pakaian seragam, mengelola kelas, kesemuanya diperhatikan oleh siswa. Di dalam kelas guru perlu melakukan berbagai hal yang dapat mendukung keberhasilan program pendidikan karakter disiplin di antaranya menjalin hubungan erat dan hangat dengan siswa, menjadikan ruang kelas sebagai laboratorium disiplin bagi siswa, mengontrol perilaku sisa, dan menyediakan waktu untuk mengatasi masalah-maslah perilaku yang tidak sesuai dengan aturan yang seharusnya.

Hasil penelitian menunjukkan bahwa kesesuaian RPP berkarakter yang dibuat oleh guru pada keempat sekolah terhadap standar proses Permendiknas dan pengembangan karakter belum maksimal. Bahkan salah satu dari keempat sekolah tersebut ada yang tidak membuat RPP sebagai pedoman dalam mengajarnya, yaitu SMP Swasta IT Rahmat. Pendidikan karakter diartikan sebagai penanaman nilai-nilai karakteristik seorang peserta didik, tetapi, seiring dengan perubahan cara mengajar pada saat ini, sepertinya para pendidik harus dituntut adanya kembali penanaman nilai-nilai karakteristik kedalam kegiatan pendidikan di setiap proses belajar mengajar. Hal ini sejalan dengan penelitian Diani (2015: 243-255) yang berpendapat bahwa perangkat pembelajaran fisika berbasis pendidikan karakter sangat valid, sangat praktis dan sangat efektif. 


\section{Pembahasan Model Pendidikan Karakter}

Untuk mendukung visi misi keempat sekolah kaitannya dengan penerapan pendidikan karakter, model yang ditawarkan pada keempat sekolah sebagai locus penelitian adalah dengan menggunakan pendekatan norma kepada seluruh warga sekolah, khususnya kepada seluruh siswanya. Secara teknis, untuk mencapai tujuan pendidikan karakter dalam proses pembelajaran IPA, guru IPA memiliki peranan penting untuk menanamkan nilai-nilai karakter melalui mata pelajaran IPA itu sendiri. Pembahasan ini lebih difokuskan pada peranan guru dalam membentuk karakter siswa.

Beberapa alasan pendidikan karakter perlu diintegrasikan pada mata pelajaran IPA adalah: Pertama, pendidikan karakter membangun hubungan baik. Ketika siswa berinteraksi dengan teman sebaya dan guru, hubungan baik akan terjalin di antara mereka di ruang kelas. Hubungan ini tidak hanya sangat bermanfaat baik secara sosial maupun personal, namun juga meningkatkan manajemen ruang kelas. Pendidikan karakter menciptakan lingkungan sekolah yang positif. Dalam pembelajaran di kelas, kegiatan diskusi dan kegiatan lain membuat sekolah menjadi memiliki atmosfer positif. Siswa berinteraksi dengan teman sebaya dan hubungan siswa dengan guru semakin menguat. Pendidikan karakter memungkinkan guru untuk berbagi pengalaman hidup.

Kedua, pendidikan karakter itu mudah dilakukan. Pendidikan karakter tidak harus menghabiskan waktu beberapa jam di kelas. Namun, dapat dilakukan selama 5 menit di awal pembelajaran untuk mendiskusikan hal-hal menarik dan mutakhir. Ketiga, pendidikan karakter dapat mengubah dunia. Siswa SMP akan menjadi orang dewasa di masa depan. Mereka akan membentuk masyarakat. Saling berorganisasi dan mengubah dunia dengan menciptakan lingkungan yang lebih kondusif karena telah mampu memimpin dirinya sendiri untuk membentuk karakternya.

Guru juga memiliki peran yang sangat vital dan fundamental dalam membimbing, mengarahkan, dan mendidik siswa dalam proses pembelajaran. Karena peran mereka yang sangat penting itu, keberadaan guru bahkan tak tergantikan oleh siapapun atau apapun sekalipun dengan teknologi canggih. Alat dan media pendidikan, sarana prasarana, multimedia dan teknologi hanyalah media atau alat yang hanya digunakan sebagai teacher's companion (sahabat-mitra guru). Guru dapat mengembangkan karakter siswa dengan membuat kondisi yang nyaman dan menyenangkan bagi siswa untuk belajar sehingga karakter dapat terbangun melalui kegiatan pembelajaran. Guru memberi bimbingan, pemahaman dan pengaruh. Siswa dapat menikmati proses pembelajaran dengan senang hati.

Guru perlu mengembangkan nilainilai karakter, seperti kepedulian, kejujuran, keadilan, tanggungjawab, dan rasa hormat terhadap diri dan orang lain, serta ketekunan, etos kerja yang tinggi, dan kegigihan, sehingga guru memiliki karakter yang baik. Oleh karena itu, ketika guru harus membentuk siswa agar berkarakter kuat, guru itu sendiri sudah memilikinya, sehingga siswa dapat meneladani perilaku, sikap, dan etika guru yang dapat diamati dan dilihat siswa dalam kehidupan sehari-hari.

Guru yang berkarakter adalah guru yang memiliki nilai dan keyakinan yang dilandasi hakikat dan tujuan pendidikan serta digunakan sebagai kekuatan moral dalam menjalankan tugasnya sebagai pendidik. Oleh karena itu, guru yang berkarakter kuat memiliki kemampuan mengajar, dan juga dapat menjadi teladan bagi siswanya. Jadi dalam membentuk siswa yang berkarakter kuat dan positif, 
guru haruslah memiliki karakter yang kuat pula.

Berdasarkan hasil pembahasan diatas, maka dapat disimpulkan bahwa penelitian ini sejalan dengan Muslich (2011) yang menjelaskan bahwa pendidikan merupakan mekanisme institusional yang akan menyeimbangkan pembinaan karakter bangsa dan berfungsi sebagai media mencapai tiga hal yang prinsipel, meliputi: pertama, pendidikan sebagai sarana untuk reaktifitas karakter luhur bangsa Indonesia. Secara historis bangsa Indonesia adalah bangsa yang memiliki karakter kepahlawanan (heroism character), nasionalisme, sifat heroik, semangat kerja keras (laboriously), serta berani menghadapi tantangan, Kedua, pendidikan sebagai sarana untuk membangkitkan karakter bangsa yang dapat mengakselerasi pembangunan sekaligus sebagai mobilisasi potensi domestik untuk meningkatkan daya saing bangsa; ketiga, pendidikan sebagai sarana untuk menginternalisasi kedua aspek diatas yakni reaktivasi sukses budaya masa lampau dan karakter inovati serta kompetitif, kedalam sendi-sendi kehidupan dan program pemerintah ini harus berupa suatu concerted efforts dari seluruh masyarakat dan pemerintah.

\section{KESIMPULAN}

Dari hasil penelitian yang telah dilakukan dapat ditarik kesimpulan sebagai berikut:

1. a. SMP Negeri 1 Patumbak telah menerapkan 9 nilai pendidikan karakter dengan persentase $50 \%$

b. SMP Swasta Madani Marindal 1 telah menerapkan 11 nilai pendidikan karakter dengan persentase $55 \%$

c. SMP Swasta Pondok Pesantren AlHusna telah menerapkan 13 nilai pendidikan karakter dengan persentase $72 \%$

d. SMP Swasta IT Rahmat telah menerapkan 9 nilai pendidikan karakter dengan persentase $50 \%$
2. a. SMP Negeri 1 Patumbak menerapkan karakter religius, demokrasi, jujur, rasa ingin tahu, semangat kebangsaan, toleransi, disiplin, peduli lingkungan, dan kerja keras.

b. SMP Swasta Madani Marindal 1 menerapkan karakter religius, demokrasi, jujur, rasa ingin tahu, semangat kebangsaan, toleransi, disiplin, peduli lingkungan, kerja keras dan tanggung jawab

c. SMP Swasta Pondok Pesantren AlHusna menerapkan karakter religius, mandiri, jujur, rasa ingin tahu, semangat kebangsaan, toleransi, disiplin, peduli lingkungan, kerja keras, peduli sosial, tanggung jawab, kreatif, inovatif

d. SMP Swasta IT Rahmat menerapkan karakter religius, tanggung jawab, jujur, rasa ingin tahu, semangat kebangsaan, toleransi, disiplin, peduli lingkungan, dan kerja keras

3. Faktor pendukung implementasi pendidikan karakter yaitu perangkat pembelajaran, kerja sama antar warga sekolah, dan peraturan sekolah beserta sanksi maupun dispensasinya, sedangkan faktor penghambat implementasi pendidikan karakter yaitu perangkat pembelajaran yang belum dilengkapi oleh guru, guru yang kurang tegas, peraturan yang kurang mengikat, serta siswa yang kurang peka terhadap pembinaan karakter disekolahnya.

\section{DAFTAR PUSTAKA}

Benninga, J. S., Berkowitz., Kuehn, P., \& Smith, K. (2003). The relationship of character education implementation and academic achievement in elementary schools. Journal of research in character education 1(1): 19-32. 
Depdiknas. (2010). Buku Induk Pembangunan Karakter. http://wartapedia.com.

Diani, Rahma. (2015). Pengembangan Perangkat Pembelajaran Fisika Berbasis Pendidikan Karakter Dengan Model Problem Based Instruction. Jurnal Ilmiah pendidikan Fisika Al-Biruni 04(2):243-255.

Ikhwanuddin. (2012). Implementasi Pendidikan Karakter Kerja Keras dan Kerja Sama dalam Perkuliahan. Jurnal pendidikan Karakter. Tahun II, No.2. 153-163.

Jaya, I.M., Sadia, I.W,.\& Arnyana, I.B.P. (2014). Pengembangan Perangkat Pembelajaran Biologi Bermuatan Pendidikan Karakter Dengan Setting Guided Inquiry Untuk Meningkatkan Karakter dan Hasil Belajar siswa SMP. e-Journal Program Pascasarjana Universitas Pendidikan Ganesha. Vol 4. 1-12.

Mukromin. (2010). Implementasi Pendidikan Karakter di Pesantren. Jurnal Al-Qalam XIII (9): 131-133. 2010.

Muslich, Masnur. (2011). Pendidikan Karakter Menjawab Tantangan Krisis Multidimensional. Jakarta: Bumi Aksara.

Salirawati, Das. (2012). Percaya Diri, Keingintahuan, dan Berjiwa Wirausaha: Tiga Karakter Penting Bagi Peserta Didik. Jurnal Pendidikan Karakter. Tahun II, No.2. 213-224.

Sani, Ridwan A. (2011). Pendidikan Karakter di Pesantren. Medan: Citapustaka Media Perintis.

Siswanto. (2013). Pendidikan Karakter Berbasis Nilai-Nilai Religious. Jurnal Tadris 8(1): 103-106.

Sjarkawi. (2006). Pembentukan Kepribadian Anak: Peran Moral, Intelektual, Emosional dan Sosial sebagai Wujud Integritas
Membangun Jati Diri. Jakarta: Bumi Aksara.

Skaggs, G \& Bondenhorn, N. (2006). Relationships Between Implementing Character Education, Student Behavior, and Student Achievement. Journal of Advanced Academics, 18, 82-144.

Suharjana. (2012). Kebiasaan Berprilaku Hidup Sehat dan Nilai-Nilai Pendidikan Karakter. Jurnal Pendidikan Karakter. Tahun II, No.2. 189-201.

Zuhriy, M. S. (2011). Budaya Pesantren dan Pendidikan Karakter Pada Pondok Pesantren Salaf. Jurnal Walisongo 19(2): 292-293. 